Н. И. Ковалевская

Белорусский государственный технологический университет

\title{
ЧИТАТЕЛЬСКИЙ ДНЕВНИК КАК ИНСТРУМЕНТ СМЫСЛОВОГО ЧТЕНИЯ
}

Современное образование не успевает актуализировать традиционные формы обучения на фоне быстро развивающегося информационного общества. Классические методы работы с текстом теряют свою привлекательность. Информационное пространство заставляет по-новому взглянуть на само определение значения слова «чтение».

В статье рассмотрена актуальность развития навыков смыслового чтения у детей, охарактеризованы умения, составляющие навыки смыслового чтения. Отдельное внимание уделено рассмотрению возможностей читательского дневника как средства развития навыков смыслового чтения.

Проведен анализ печатных читательских дневников, разработанных издательствами «Аверсэв», «Эксмо», «Высновы», «МИФ», и электронных. Дана сравнительная характеристика: описаны структура изданий, задания, памятки, закладки.

В качестве рекомендаций предложена концепция читательского дневника, который совмещает традиционную и нетрадиционную формы.

Ключевые слова: смысловое чтение, умения смыслового чтения, навыки смыслового чтения, читательский дневник.

Для цитирования: Ковалевская Н. И. Читательский дневник как инструмент смыслового чтения // Труды БГТУ. Сер. 4, Принт- и медиатехнологии, 2021. № 2 (249). С. 117-125.

\section{N. I. Kovalevskaya \\ Belarusian State Technological University}

\section{FOREIGN METHODS OF ATTRACTION CHILDREN TO READ}

Modern education does not have time to update traditional forms of education against the background of a rapidly developing information society. Classic methods of working with text are losing their appeal. The information space forces us to take a fresh look at the very definition of the meaning of the word "reading".

The article examines the relevance of the development of semantic reading skills in children, characterizes the skills that make up the skills of semantic reading. Special attention is paid to considering the possibilities of a reader's diary as a means of developing semantic reading skills.

The analysis of printed readers' diaries, developed by the publishing houses "Aversev", "Eksmo", "Vysnovy", "MYTH", and electronic. A comparative characteristic is given: the structure of editions, tasks, memos, bookmarks are described.

As a recommendation, the concept of a reader's diary is proposed, which combines traditional and non-traditional forms. As a recommendation, the concept of a reader's diary is proposed, which combines traditional and non-traditional forms.

Key words: semantic reading, semantic reading skills, semantic reading skills, reader's diary.

For citation: Kovalevskaya N. I. Foreign methods of attraction children to read. Proceedings of BSTU, issue 4, Print- and Mediatechnologies, 2021, no. 2 (249), pp. 117-125 (In Russian).

Введение. Впервые проблема обучения смысловому чтению возникла в середине XIX в., и это выразилось в противоречии между навыком механического озвучивания текста и пониманием учеником информации, изложенной в тексте. В XXI в. в современном образовании смысловое чтение стало приоритетной проблемой мирового масштаба.

Советом Европы определены пять ключевых компетенций образованного человека, в число которых входят компетенции умения работать с информацией, связанные с возрастанием информатизации общества. Это владение технологиями смыслового продуктивного чтения, понимание их применения, слабых и сильных сторон и способов критического суждения в отношении информации, распространяемой массмедийными средствами и рекламой [1].

Умение запрашивать, искать, отбирать, оценивать и перерабатывать нужную информацию является неотъемлемой частью функциональной грамотности человека.

Современные дети обладают системно-смысловым типом сознания, у них преобладает смысловая сфера как ориентация на смысл деятельности, что вызывает необходимость формирования смыслового восприятия и переработки текстовой информации уже на начальном этапе обучения чтению [2]. В настоящее время усиливается тенденция отказа детей от чтения книг и предпочтение других источников информации. Экранная зависимость 
приводит к неспособности ребенка концентрироваться на каком-либо занятии. Таким детям необходима постоянная внешняя стимуляция, которую они привыкли получать с экрана, им трудно воспринимать слышимое и читать, понимая отдельные слова и короткие предложения, они не могут связывать их, в результате не понимают текста в целом $[3,4]$.

Психологическими составляющими смыслового чтения являются: зрительное восприятие, произвольное внимание, смысловая память, логическое мышление, мотивация.

Выбирая средства, методы, техники и технологии изучения любого предмета, необходимо работать над смысловой стороной чтения.

Для обучения смысловому чтению используются следующие методы и приемы:

- развитие умения анализировать задание;

- поиск ключевых слов в задании и умение вчитываться в инструкцию;

- ответы на поставленные вопросы (как письменные, так и устные);

- определение последовательности событий в прочитанном тексте;

- формулирование простых выводов после прочтения текста; лицу;

- преобразование прочитанного текста в таб-

- сопоставление иллюстративного материала с текстовой информацией;

- объяснение различных ситуаций с помощью прочитанного текста;

- умение, опираясь на прочитанный текст, доказывать свою точку зрения, опровергать какиелибо утверждения;

- нахождение нужной информации в различных информационных источниках: словарях, справочниках, энциклопедиях и т. д. [5, 6]

Такие глобальные процессы информатизации общества, как увеличение с каждым годом количества текстовой информации, предъявление новых требований к ее анализу, систематизации и скорости ее переработки, поставили родителей, педагогов и издателей перед необходимостью разработки новых подходов к обучению чтению.

Читая различные произведения и записывая общее содержание в читательский дневник, ребенок тренирует не только навыки письма, но и учится анализировать произведение, выделять основную мысль автора, понять, что же своим произведением автор хотел донести до читателя. Ребенок развивает читательские навыки, культуру читателя $[7,8]$.

Основная часть. На сегодняшний день существует множество видов и форм читательских дневников.

Формы читательских дневников можно подразделить на две большие группы: традиционные и нетрадиционные. К традиционным дневникам относятся печатные версии читательских дневников, а к нетрадиционным - электронные $[9,10,11]$.

Проведем маркетинговое исследование читательских дневников, существующих на белорусском рынке.

В качестве объектов сравнительного анализа были выбраны читательские дневники издательств «Аверсэв», «Высновы», «Эксмо», «МИФ», электронные дневники.

Дневник издательства «Аверсэв» (рис. 1) предназначен для учащихся младших классов.

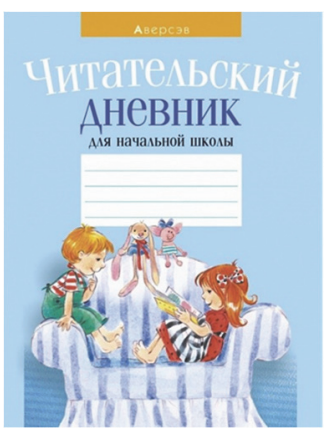

Рис. 1. Читательский дневник издательства «Аверсэв»

Издание поможет ребенку систематизировать свои впечатления от книги, которую он читает, глубже понять смысл произведения, а родителям и учителям осуществить контроль над процессом чтения.

Дневник имеет большей частью положительные отзывы от пользователей. Многим импонирует, что в нем есть задания, в которых нужно проявить свои творческие способности (например, нарисовать) (рис. 2), а также присутствует график чтения книг, который ребенок может составить для себя самостоятельно.

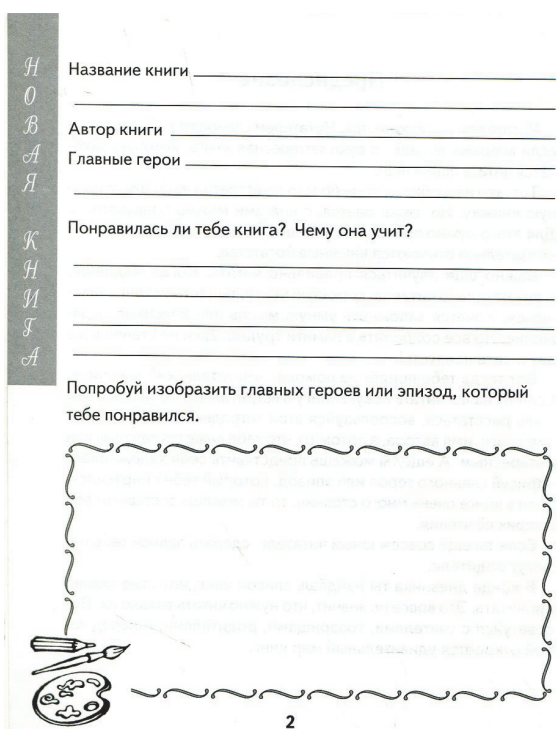

Рис. 2. Разворот читательского дневника издательства «Аверсэв» 
Дневник помогает тренировать память, учит анализировать прочитанное, понимать его смысл, находить главное, выражать мысли, развивать речь и воображение.

Еще одним белорусским изданием является читательский дневник издательства «Высновы» (рис. 3).

Дневник рассчитан на учащихся начальной школы. Это издание предназначено для записи прочитанных произведений, содержания, мыслей и впечатлений.

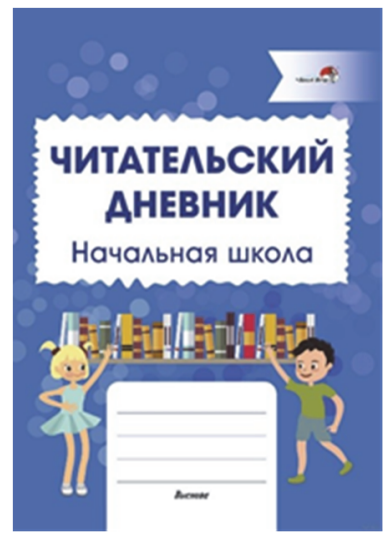

Рис. 3. Читательский дневник издательства «Высновы»

Его содержание довольно стандартное. Даны рекомендации, как работать с дневником. Есть список книг, который ребенок заполняет самостоятельно. Для записи на каждую книгу отводится две страницы. Задания слишком простые (рис. 4).

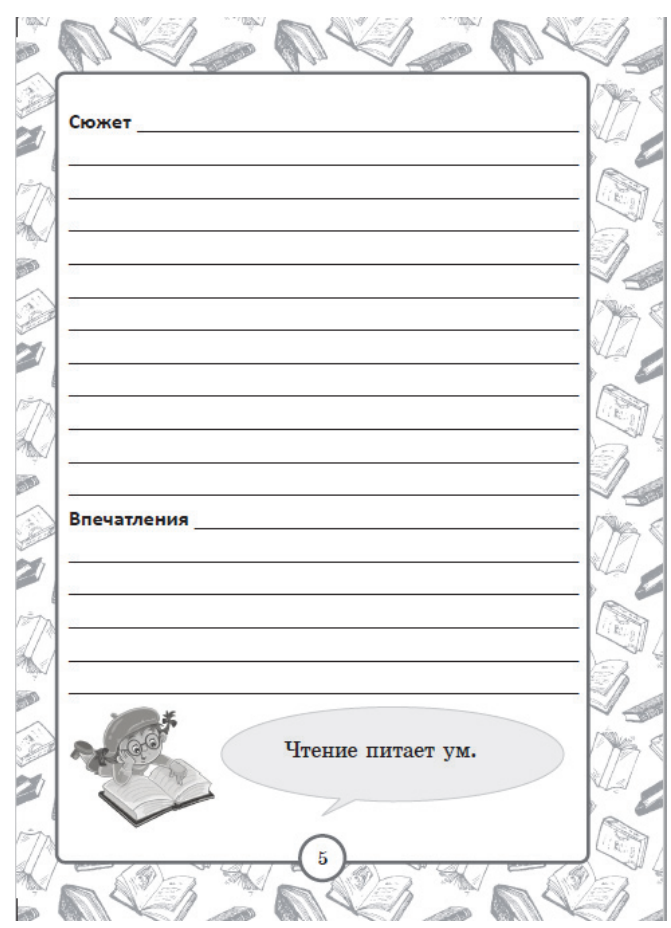

Рис. 4. Разворот читательского дневника издательства «Высновы»
Оформление издания не привлечет внимание ребенка.

Интересным дизайном выделяется читательский дневник «Диппер и Мэйбл. Гравити Фолз» (издательство «Эксмо»).

Читательский дневник интересен ярким оформлением обложки (рис. 5), на которой расположены герои популярного мультфильма «Гравити Фолз».
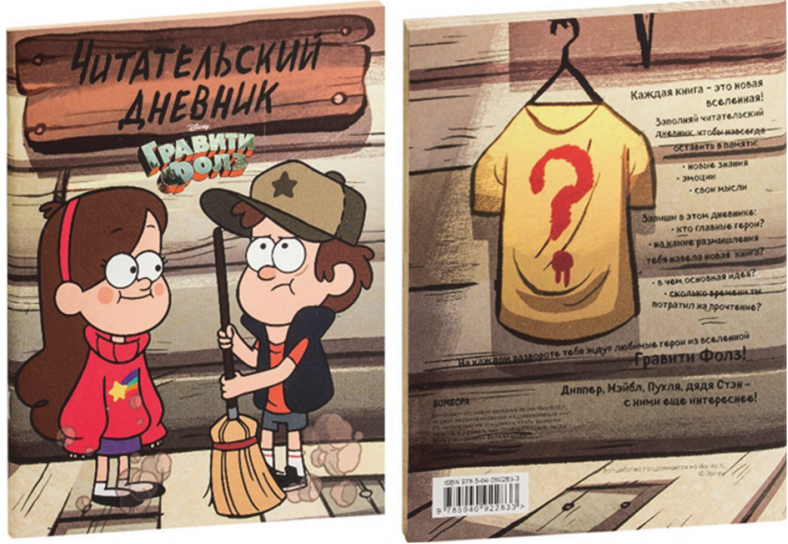

Рис. 5. Читательский дневник издательства «Эксмо»

Несмотря на яркое оформление, содержание дневника довольно бедно. Страницы пустые, оформлены в форме таблицы (рис. 6).

Отсутствуют пояснения, для чего ведется дневник. Нет творческих, стимулирующих заданий.

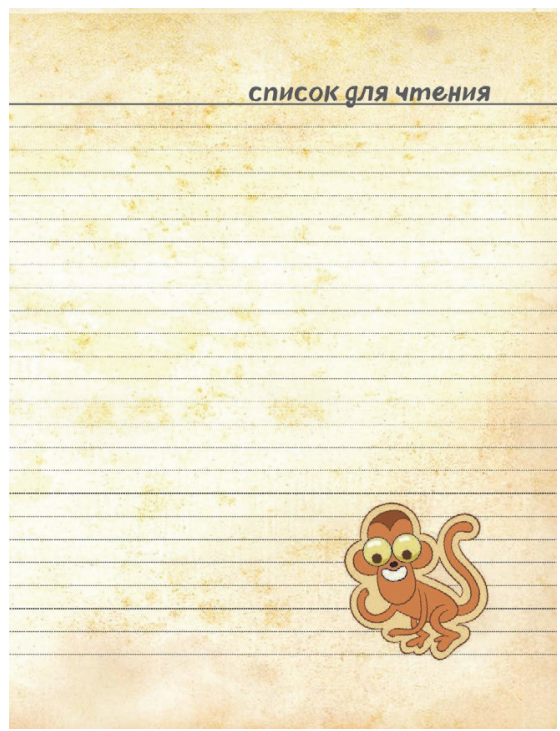

Рис. 6. Страницы читательского дневника издательства «Эксмо»

На момент покупки учащихся привлекут герои любимого мультфильма и яркое оформление, но поскольку само содержание дневника оригинальностью не отличается, пользователю быстро наскучит его заполнять. 
Читательский дневник «Ученая сова» издательства «Эксмо» очень нравится детям: красивое оформление, очень милые картинки, цитаты (рис. 7).

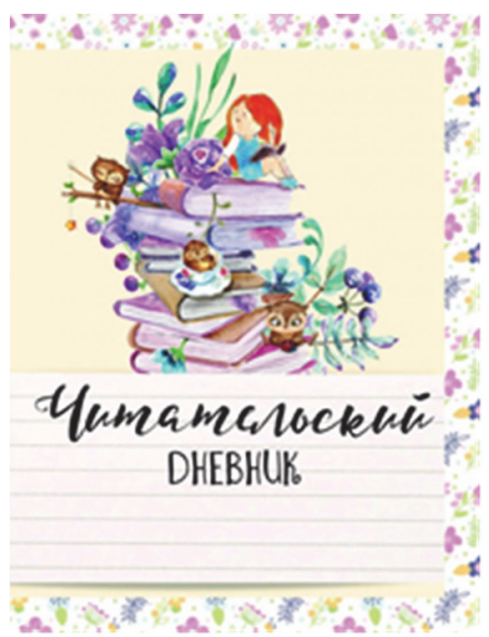

Рис. 7. Читательский дневник «Ученая сова» издательства «Эксмо»

На каждом развороте красивое оформление с рамочками и рисунками милых персонажей (рис. 8).

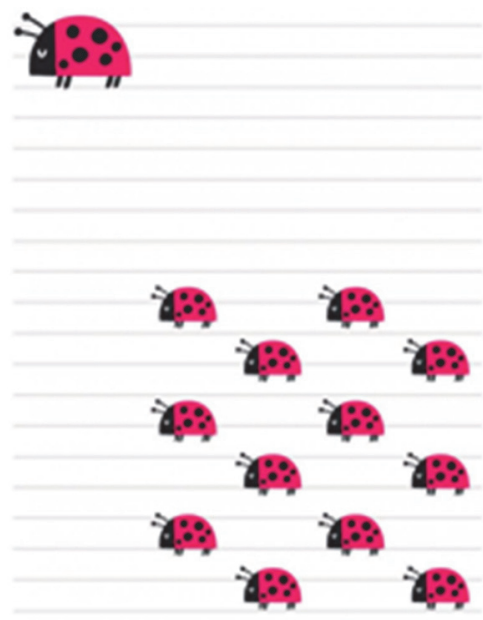

Рис. 8. Разворот читательского дневника «Ученая сова» издательства «Эксмо»

Однако отсутствие пояснений, для чего ведется дневник и как его вести, творческих и интересных заданий сделает заполнение такого дневника скучным и утомительным.

На редкость интересным оказался читательский дневник Марты Райцес (рис. 9), выпущенный издательством «МИФ».

Издание предназначено для детей 8-14 лет. На обороте перечислено, чему может научить этот читательский дневник.

Дневник состоит из двух частей. В первой приводится 5 причин, почему нужно вести дневник (рис. 10), объясняется, чем можно заниматься в данном издании после прочтения книги: например, записывать свои впечатления и понравившиеся цитаты, рисовать любимых героев, составлять словарь непонятных слов, придумывать кроссворд или интеллект-карту, искать рецепт блюда, упоминавшегося в книге, придумывать фанфик. В качестве примера приводятся фамилии знаменитых людей, которые записывали мысли о прочитанном.

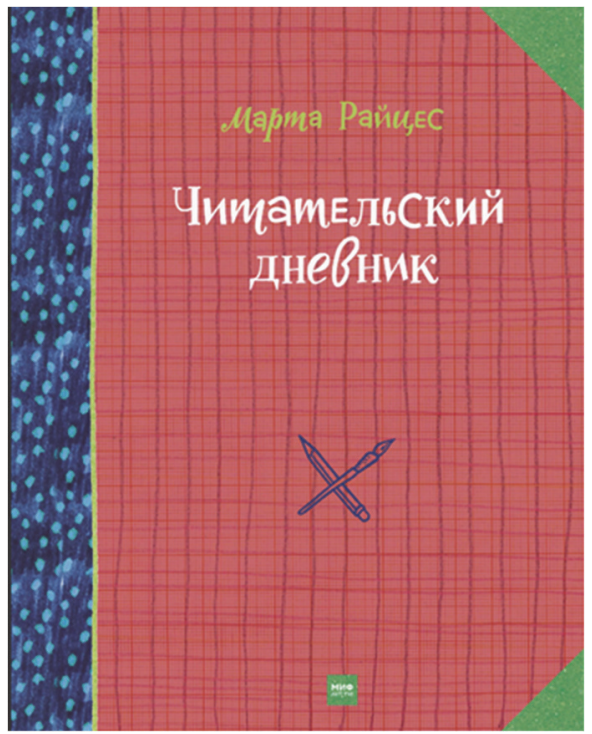

Рис. 9. Читательский дневник Марты Райцес издательства «МИФ»

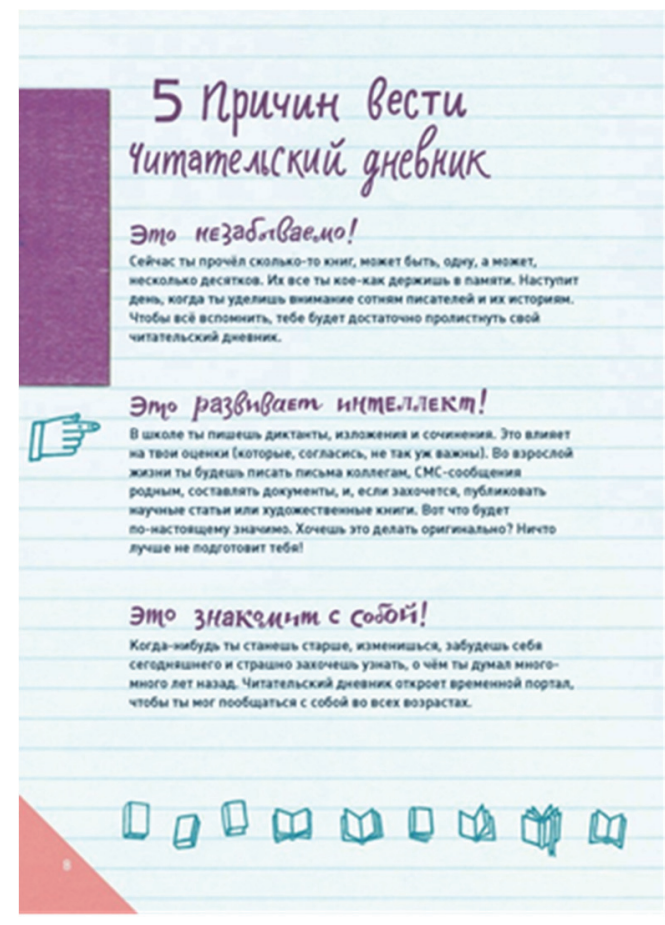

Рис. 10. Страница читательского дневника Марты Райцес издательства «МИФ»

В первой части также есть примеры, составленные детьми, учениками Марты, что является 
мотивирующим фактором. Это дает хороший стимул читателю вести дневник. Приведены пояснения, что можно делать в читательском дневнике, советы о том, как писать о своих мыслях и чувствах, рекомендации по оформлению рисунков, составлению словаря книги, примеры фанфиков, рецензии.

Интересен раздел «Тайны двух полок» (рис. 11). Читателю предлагается разделить книги на те, которые уже прочитаны, и те, которые еще предстоит прочитать. Таким образом, ребенок будет ставить перед собой цель - переместить книгу с одной полки на другую и пополнить свою библиотеку еще одной хорошей книгой.
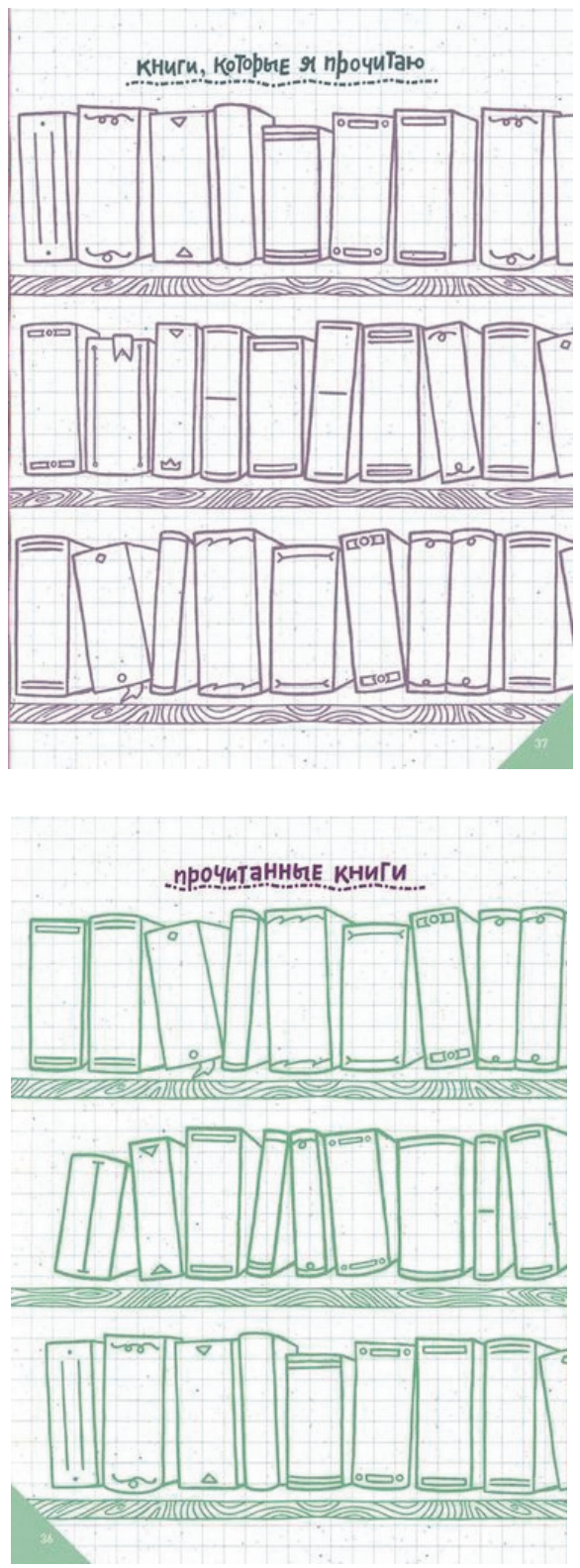

Рис. 11. Раздел «Тайна двух книжных полок»

Вторая часть дневника - творческие страницы, которые читатель может заполнить как пожелает (рис. 12).
Прочитав книгу, ребенок должен самостоятельно выбрать, какое задание ему бы хотелось выполнить: составить кроссворд или словарь, написать впечатления или фанфик, найти рецепт, нарисовать иллюстрацию и т. д. Затем он сможет выполнить выбранное задание, в котором есть специальные пустые страницы. Там ребенок пишет название книги, автора, переводчика, дату прочтения и заполняет страницы.
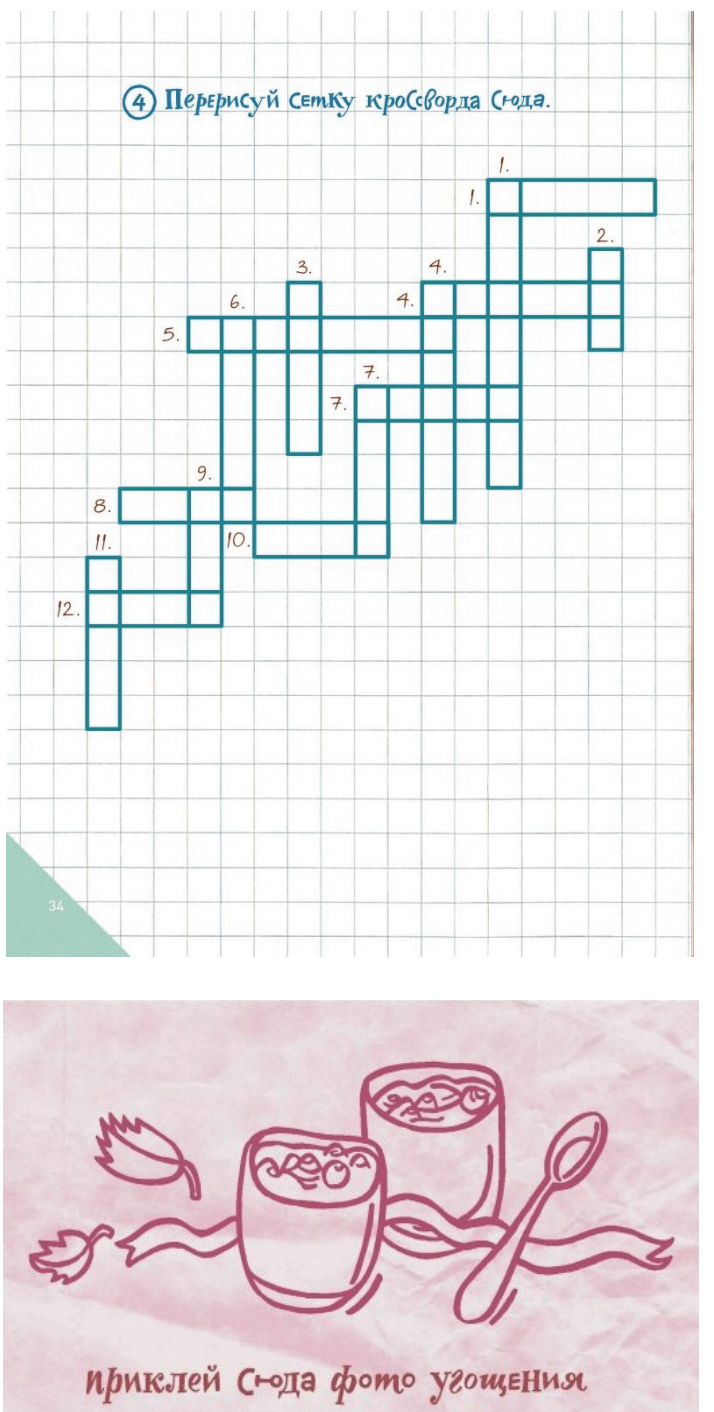

Рис. 12. Творческие страницы

Не нужно стараться уместить свои мысли в границах отведенных страниц, не обязательно писать и делать только то, что предлагает автор. Страницы читательского дневника можно использовать как угодно - все зависит от фантазии ребенка.

Дневник дает полную свободу действий. В него можно выписывать понравившиеся цитаты из книг, можно рисовать иллюстрации к прочитанным книгам, выписывать интересные факты, придумывать кроссворды по книгам, отзывы.

Необходимо отметить, что задачи дневника довольно разнообразны. Они развивают у ребенка 
способность творчески мыслить, пополняют словарный запас. Например, составить кроссворд или словарь книги, описать впечатления или придумать фанфик, нарисовать иллюстрацию к книге.

Все задания носят развлекательный характер, направлены на развитие логического и творческого мышления.

Читательский дневник научит:

- свободно выражать и записывать на бумаге свои мысли;

- рассуждать логически, анализировать, находить закономерности, работать с информацией;

- обращать внимание на детали;

- запоминать важное.

Поможет развить писательское мастерство, расширит кругозор, научит через анализ литературного произведения лучше понимать себя и других людей, привьет любовь к литературе и чтению, разнообразит досуг.

Дневник написан живым разговорным языком, побуждающим ребенка относиться ко всему, что он делает, легко и не бояться творить.

Привлекает дизайн дневника, каждый разворот оформлен по-новому: большая клетка, косая линия, точечки, разноцветные страницы и т. д.

Однако следует отметить, что в дневнике страницы рассчитаны на анализ восьми книг.

Анализ печатных (традиционных) дневников показал, что чаще всего простая табличная форма дневников неинтересна для учащихся, а заполнение такой формы для школьников - скучное и утомительное занятие. Также ведение читательского дневника может дать отрицательный эффект: и вместо того, чтобы развить интерес учащегося к чтению, будет способствовать охлаждению интереса к знакомству с литературными произведениями. На такие дневники достаточно много негативных отзывов потребителей. Они отмечают, что данные издания скучные, нет мотивации их заполнения, шаблонные задания.

Однако в настоящее время появляется все больше разновидностей читательских дневников, которые помогают учащимся выражать собственное мнение и ставить проблемные вопросы.

Нетрадиционный читательский дневник - электронный дневник - это дневник читателя в новом формате, созданный с помощью различных компьютерных программ. Это те же впечатления о прочитанной книге, но уже представленные на веб-странице с помощью различных интернетсервисов и программ [5].

Электронный читательский дневник способствует:

- развитию информационной грамотности учащихся;

- воспитанию их информационной культуры;

- приобретению навыков сетевого общения;
- формированию навыков самостоятельного отбора информации;

- творческой самореализации $[4,12]$.

У каждого учащегося может быть оригинальный дневник. Все зависит от его собственного воображения, смысловой функции дневника и уровня информационной грамотности ребенка.

Такой читательский дневник может отражать личные впечатления владельца дневника о прочитанной книге, список избранных, уже прочитанных или тех книг, которые планируется прочитать. Дневник может быть оформлен в виде таблицы, книжки, слайд-шоу, отсканированных изображений, в виде самостоятельно созданных видеороликов, размещенных на YouTube, это также могут быть собственные вики-странички, блоги и многое др.

Вариантов оформления электронных читательских дневников достаточно много:

- ребус (можно зашифровать название книги, имена героев, автора);

- облако слов (можно необычно и ярко представить книгу; нужно подобрать слова и выбрать форму облака, тогда облако из слов получится в виде выбранной ранее фигуры);

- коллаж (композиция, в которой можно соединить несколько изображений, создать фон и сделать красивую надпись);

- дневник читателя в форме книги (учащиеся могут создавать в любом текстовом редакторе или сделать его в виде презентации PowerPoint);

- дневник в виде путешествий литературных героев на Google-карте (на карте учащимся отмечаются географические объекты, которые встречаются в литературном произведении: страны, населенные пункты, реки, моря, озера, маршруты; метки на карте дополняются описаниями, фрагментами из произведений, картинами художников об этих событиях, фотографиями, ссылками на интернет-ресурсы, видео, аудиокниги);

- аудиодневник читателя (учащиеся могут отразить свое отношение к прочитанному произведению, пересказать его, озвучить свои рекомендации слушателям-сверстникам, а также записать творческое эссе или сделать звуковую открытку с использованием картинки, анимации, голоса);

- блог (сайт, на котором учащийся размещает отзывы о прочитанных книгах) может содержать коллективную работу учеников;

- видеоблог (форма блога, в котором основным средством передачи информации является видео; можно записать видеоинтервью о любимой книге, создать бук-трейлер) [5].

Электронный читательский дневник неограничен по объему, но ограничен по времени заполнения (чтение с экрана). 
Чтение подростков все чаще трансформируется, перемещается из оффлайн в онлайн. «Электронная» культура оказывает на детское чтение все большее влияние. Меняются привычки и способы взаимодействия детей и подростков с информацией, в том числе с текстами в разных форматах [13].

Детям необходима постоянная внешняя стимуляция, которую они привыкли получать с экрана, им трудно воспринимать слышимое и читать: понимая отдельные слова и короткие предложения, они не могут связывать их, в результате не понимают текста в целом. Необходимо разрабатывать новые подходы к обучению чтению.

Международные исследования показывают тесную связь между качеством чтения в электронной среде и качеством чтения текста, представленного на бумажном носителе, т. е. если учащиеся показывают высокий или низкий уровень грамотности, читая на бумажном носителе, то они показывают аналогичные результаты, читая в электронной среде [14].

Обучение экранному чтению требует как теоретического переосмысления понятия чтения, так и создания новых технологий обучения.

В качестве средства для решения обозначенной проблемы мы разработали концепцию читательского дневника элементами дополненной реальности. Это даст возможность совместить достоинства печатного и электронного дневников. Ребенок будет учиться самостоятельно устанавливать соотношение между собой, текстом и окружающим миром.
Заключение. На современном этапе развития информационного общества необходимо научить детей работать не только с печатными, но и с электронными изданиями. Все это связано с таким понятием, как функциональная грамотность способность человека использовать умения чтения и письма в условиях получения информации из текста и в целях передачи такой информации. В этом плане интересны слова Алвина Тофлера: «B XXI веке безграмотным будет считаться не тот, кто не умеет читать и писать, а тот, кто не умеет учиться и переучиваться, используя умения читать и писать».

Реализация оценочного компонента предоставляет широкие возможности по активизации, планированию чтения, коррекции его, совместной работе после прочитанного, способствует развитию самостоятельного, творческого мышления, ответственного отношения к чтению, повышает мотивацию самосовершенствования [1].

Читательский дневник стал инструментом для формирования смыслового чтения: «умения думать до чтения, во время чтения и после чтения» [15]. Он развивает познавательный интерес и стимулирует учащихся к систематическому чтению, обусловливает формирование важных качеств личности: ответственности, умения преодолевать трудности, самостоятельности, творческой деятельности.

Ведение грамотно и логически структурированного читательского дневника поможет развить у ребенка стойкий интерес к чтению и повысить мотивацию к осмысленному чтению через положительные эмоции.

\section{Список литературы}

1. Методы и приемы обучения смысловому чтению обучающихся в учебнике на ценностно-смысловой основе [Электронный ресурc]. URL: https://cyberleninka.ru/article/n/metody-i-priemy-obucheniyasmyslovomu-chteniyu-obuchayuschihsya-v-uchebnike-na-tsennostnosmyslovoy-osnove (дата обращения: 21.07.2021).

2. Смысловая сфера современного ребенка как основа профилактики, коррекции и развития [Электронный ресурс]. URL: https://cyberleninka.ru/article/n/smyslovaya-sfera-sovremennogo-rebenka-kak-osnovaprofilaktiki-korrektsii-i-razvitiya (дата обращения: 19.06.2021).

3. Человек в современном мире: тенденции и потенциальные возможности развития [Электронный pecypc]. URL: http://psyrus.ru/library/pdf/novgorod_sbornik.pdf (дата обращения: 21.07.2021).

4. Формирование навыков смыслового чтения [Электронный ресурc]. URL: https://dspace.tltsu.ru/ bitstream/123456789/883/1/\%D0\%AF\%D1\%88\%D0\%B8\%D0\%BD\%D0\%B0\%20\%D0\%9D.\%D0\%92._\% D0\%9F\%D0\%9F\%D0\%9E\%D0\%B1_1202.pdf (дата обращения: 20.06.2021).

5. Читательский дневник: исторйя и современность [Электронный ресурc]/ URL: http://elib.cspu.ru/ xmlui/bitstream/handle/123456789/4739/\%D0\%97\%D1\%8B\%D1\%80\%D1\%8F\%D0\%BD\%D0\%BE\%D0 $\% \mathrm{~B} 2 \% \mathrm{D} 0 \% \mathrm{~B} 0 \_\% \mathrm{D} 0 \% 94 \_\% \mathrm{D} 0 \% 90 \_\% \mathrm{D} 0 \% 92 \% \mathrm{D} 0 \% 9 \mathrm{~A} \% \mathrm{D} 0 \% \mathrm{~A} 0$. pdf? sequence=1\&isAllowed=у (дата обращения: 20.06. 2021$)$.

6. Читательский дневник: эволюция стиля и содержания [Электронный ресуpc]. URL: https://kanzoboz.ru/ article/chitatelskiy_dnevnik_evolyutsiya_stilya_i_soderjaniya/ (дата обращения: 18.07.2021)

7. Стефановская Н. А. Социологические исследования чтения: теория, методика, практика. М.: Литера, 2013. 143 c.

8. Чтение и время: материалы VI науч.-практ. конф. 2014 г. / Брян. обл. науч. универс. б-ка имени Ф. И. Тютчева. Брянск, 2014. URL: http://libryansk.ru/files/project/chtenie_i_vremya/2.html (дата обращения: 12.02.2017). 
9. Чудинова В. П. Функциональная неграмотность - проблема развитых стран // Социологические исследования. 1994. № 3. С. 98-102.

10. Чудинова В. П., Кабачек О. Л. Дети и библиотеки в меняющейся медиасреде. М.: Школьная б-ка, 2004. 336 с.

11. Куликова Е. В. Продвижение детского чтения // Как создаются читающие нации: опыт, идеи, образцы: сб. материалов / Фонд «Пушкинская библиотека», Центр книги Б-ки Конгресса США, Британский совет. М., 2006. С. 24-29.

12. Сушко Н. И. Анализ читательских интересов детей и подростков: проблемы чтения, издания и доступности печатной продукции // Труды БГТУ. Сер. IX, Издат. дело и полиграфия. 2009. Вып. XVII. C. $97-101$.

13. Ковалевская Н. И., Петрова Л. И. Читательские интересы детей и подростков: проблемы чтения // Чтение на евразийском перекрестке: материалы Междунар. форума. Челябинск, 27-28 мая 2010 г. / Челяб. гос. акад. культуры и искусств, Челябинск, 2010. С. 219-221.

14. Мелентьева Ю. П. Чтение: явление, процесс, деятельность. М.: Наука, 2010. 180 с.

15. Сушко Н. И. Проблемы и тенденции в чтении детей в условиях развития новых информационных технологий // Детская литература и воспитание: сб. тр. Междунар. науч.-практ. конф., Тверь / Тверской гос. ун-т. Тверь, 2009. С. 158-162.

\section{References}

1. Metody i priyemy obucheniya smyslovomu chteniyu obuchayushchikhsya $v$ uchebnike na tsennostno-smyslovoy osnove [Methods and techniques of teaching semantic reading of students in a textbook on a value-semantic basis]. Available at: https://cyberleninka.ru/article/n/metody-i-priemyobucheniya-smyslovomu-chteniyu-obuchayuschihsya-v-uchebnike-na-tsennostnosmyslovoy-osnove (accessed 21.07.2021).

2. Smyslovaya sfera sovremennogo rebenka kak osnova profilaktiki, korrektsii i razvitiya [The semantic sphere of the modern child as the basis of prevention, correction and development]. Available at: https://cyberleninka.ru/article/n/smyslovaya-sfera-sovremennogo-rebenka-kak-osnova-profilaktikikorrektsii-i-razvitiya (accessed 19.06.2021)

3. Chelovek v sovremennom mire: tendentsii i potentsial'nyye vozmozhnosti razvitiya [Man in the modern world: trends and potential development opportunities]. Available at: http://psyrus.ru/library/pdf/novgorod_ sbornik.pdf (accessed 21.07.2021).

4. Formirovaniye navykov smyslovogo chteniya [Formation of semantic reading skills]. Available at: https://dspace.tltsu.ru/bitstream/123456789/883/1/\%D0\%AF\%D1\%88\%D0\%B8\%D0\%BD\%D0\%B0\%20\% D0\%9D.\%D0\%92._\%D0\%9F\%D0\%9F\%D0\%9E\%D0\%B1_1202.pdf (accessed 20.06.2021)

5. Chitatel 'skiy dnevnik: istoriya i sovremennost' [Reader's diary: history and modernity]. Available at: http://elib.cspu.ru/xmlui/bitstream/handle/123456789/4739/\%D0\%97\%D1\%8B\%D1\%80\%D1\%8F\%D0\% BD\%D0\%BE\%D0\%B2\%D0\%B0_\%D0\%94_\%D0\%90_\%D0\%92\%D0\%9A\%D0\%A0.pdf?sequence=1\&is Allowed=y (accessed 20.06.2021).

6. Chitatel'skiy dnevnik: evolyutsiya stilya i soderzhaniya [Man in the modern world: trends and potential development opportunities]. Available at: https://kanzoboz.ru/article/chitatelskiy_dnevnik_evolyutsiya_stilya_ i_soderjaniya/ (accessed 18.06.2021)

7. Stefanovskaya N. A. Sotsiologicheskiye issledovaniya chteniya: teoriya, metodika, praktika [Sociological reading research: theory, methodology, practice]. Moscow, Litera Publ., 2013. 143 p.

8. Materialy VI nauchno-prakticacskoy konferentsii "Chteniye i vremya" [Materials of the scientific VI and Practical Conference "Reading and time"]. Bryansk, 2014. Available: http://libryansk.ru/files/project/chtenie_ i_vremya/2.html (accesed 20.02.2017).

9. Chudinova V. P. Functional illiteracy - the developed countries the problem. Sotsiologicheskiye issledovaniya [Sociological studies], 1994, no. 3, pp. 98-102 (In Russian).

10. Chudinova V. P., Kabachek O. L. Deti i biblioteki v menyayushcheysya mediasrede [Children and library in a changing media environment]. Moscow, Shkol'naya biblioteka Publ., 2004. 336 p.

11. Kulikova E. V. Promoting Children's Reading. Sbornik materialov "Kak sozdayutsya chitayushchiye natsii: opyt, idei, obraztsy" [Collection of materials "As the reading nations are created: experience, ideas, samples"]. Moscow, 2006, pp. 24-29 (In Russian).

12. Sushko N. I. Analysis of reading interests of children and adolescents: reading problems, publication and availability of printed materials. Trudy BGTU [Proceedings of BSTU], series IX, Printing and Publishing, 2009, issue XVII, pp. 97-101 (In Russian). 
13. Kovalevskaya N. I., Petrova L. I. Reader's interests of children and adolescents: reading problems]. Materialy Mezhdunarodnogo foruma "Chteniye na evraziyskom perekrestke" [Proceedings of the International forum "The reading on the Eurasian crossroads"]. Chelyabinsk, 2010, pp. 219-221 (In Russian).

14. Melent'yeva Ju. P. Chteniye: yavleniye, protsess, deyatel'nost' [Reading: the phenomenon, process, activity]. Moscow, Nauka Publ., 2010. 180 p.

15. Sushko N. I. Problems and tendencies in reading children in the conditions of development of new information technologies]. Sbornik trudov Mezhdunar. nauch.-prakt. konf. "Detskaya literatura i vospitaniye" [Proceedings of the International scientific-practical conference "Children's Literature and Education"]. Tver', 2009, pp. 158-162 (In Russian).

\section{Информация об авторе}

Ковалевская Наталья Ивановна - старший преподаватель кафедры редакционно-издательских технологий. Белорусский государственный технологический университет (220006, г. Минск, ул. Свердлова, 13a, Республика Беларусь). E-mail: naivs@tut.by

\section{Information about the author}

Kovalevskaya Natal'ya Ivanovna - Senior Lecturer, the Department of Editing and Publishing Technology. Belarusian State Technological University (13a, Sverdlova str., 220006, Minsk, Republic of Belarus). E-mail: naivs@tut.by 